\title{
Front Matter: Volume 7449
}

, "Front Matter: Volume 7449," Proc. SPIE 7449, Hard X-Ray, Gamma-Ray, and Neutron Detector Physics XI, 744901 (28 September 2009); doi:

$10.1117 / 12.845350$

SPIE Event: SPIE Optical Engineering + Applications, 2009, San Diego, California, SPIE. United States 


\section{PROCEEDINGS OF SPIE}

\section{Hard X-Ray, Gamma-Ray, and Neutron Defector Physics XI}

Ralph B. James

Larry A. Franks

Arnold Burger

Editors

3-6 August 2009

San Diego, United States

Sponsored and Published by

SPIE

Volume 7449

Proceedings of SPIE, 0277-786X, v. 7449 
The papers included in this volume were part of the technical conference cited on the cover and title page. Papers were selected and subject to review by the editors and conference program committee. Some conference presentations may not be available for publication. The papers published in these proceedings reflect the work and thoughts of the authors and are published herein as submitted. The publisher is not responsible for the validity of the information or for any outcomes resulting from reliance thereon.

Please use the following format to cite material from this book:

Author(s), "Title of Paper," in Hard X-Ray, Gamma-Ray, and Neutron Detector Physics XI, edited by Ralph B. James, Larry A. Franks, Arnold Burger, Proceedings of SPIE Vol. 7449 (SPIE, Bellingham, WA, 2009) Article CID Number.

ISSN 0277-786X

ISBN 9780819477392

Published by

SPIE

P.O. Box 10, Bellingham, Washington 98227-0010 USA

Telephone +1 3606763290 (Pacific Time) · Fax +1 3606471445

SPIE.org

Copyright (C) 2009, Society of Photo-Optical Instrumentation Engineers

Copying of material in this book for internal or personal use, or for the internal or personal use of specific clients, beyond the fair use provisions granted by the U.S. Copyright Law is authorized by SPIE subject to payment of copying fees. The Transactional Reporting Service base fee for this volume is $\$ 18.00$ per article (or portion thereof), which should be paid directly to the Copyright Clearance Center (CCC), 222 Rosewood Drive, Danvers, MA 01923. Payment may also be made electronically through CCC Online at copyright.com. Other copying for republication, resale, advertising or promotion, or any form of systematic or multiple reproduction of any material in this book is prohibited except with permission in writing from the publisher. The CCC fee code is 0277-786X/09/ $\$ 18.00$.

Printed in the United States of America.

Publication of record for individual papers is online in the SPIE Digital Library.

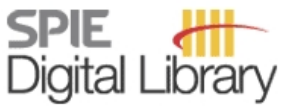

SPIEDigitalLibrary.org

Paper Numbering: Proceedings of SPIE follow an e-First publication model, with papers published first online and then in print and on CD-ROM. Papers are published as they are submitted and meet publication criteria. A unique, consistent, permanent citation identifier (CID) number is assigned to each article at the time of the first publication. Utilization of CIDs allows articles to be fully citable as soon they are published online, and connects the same identifier to all online, print, and electronic versions of the publication. SPIE uses a six-digit CID article numbering system in which:

- The first four digits correspond to the SPIE volume number.

- The last two digits indicate publication order within the volume using a Base 36 numbering system employing both numerals and letters. These two-number sets start with 00, 01, 02, 03, 04, $05,06,07,08,09,0 A, 0 B \ldots 0 Z$, followed by 10-1Z, 20-2Z, etc.

The CID number appears on each page of the manuscript. The complete citation is used on the first page, and an abbreviated version on subsequent pages. Numbers in the index correspond to the last two digits of the six-digit CID number. 


\title{
Contents
}

\author{
ix Conference Committee \\ xiii Introduction
}

\section{SESSION 1 CZT DETECTORS I}

744902 CZT device with improved sensitivity for medical imaging and homeland security applications (Invited Paper) [7449-01]

H. Chen, S. A. Awadalla, P. Marthandam, K. Iniewski, P. H. Lu, G. Bindley, Redlen

Technologies (Canada)

744904 Dual anode contact geometries for $x$-ray and gamma-ray spectroscopy and 3D localization [7449-03]

J.W. Martin, A. B. Garson III, Q. Li, K. Lee, Washington Univ. in St. Louis (United States);

M. Groza, V. Buliga, A. Burger, Fisk Univ. (United States); H. Krawczynski, Washington Univ. in St. Louis (United States)

744905 Front-end ASIC for pixilated wide bandgap detectors [7449-04]

E. Vernon, G. De Geronimo, J. Fried, Brookhaven National Lab. (United States); C. Herman,

F. Zhang, Z. He, Univ. of Michigan, Ann Arbor (United States)

\section{SESSION 2 CZT CHARACTERIZATION I}

744908 Uniformity of charge collection efficiency in Frisch collar spectrometer with THM grown CdZnTe crystals [7449-07]

A. Kargar, A. C. Brooks, Kansas State Univ. (United States); M. J. Harrison, Univ. of Florida (United States); H. Chen, S. Awadalla, G. Bindley, B. Redden, Redlen Technologies

(Canada); D. S. McGregor, Kansas State Univ. (United States)

\section{SESSION $3 \quad$ CZT DETECTORS II}

744909 Characterization of a 15-mm-long virtual Frisch-grid CZT detector array (Invited Paper) [7449-08]

A. E. Bolotnikov, Brookhaven National Lab. (United States); S. Babalola, Fisk Univ. (United States) and Vanderbilt Univ. (United States); G. S. Camarda, Y. Cui, Brookhaven National Lab. (United States); S. U. Egarievwe, Fisk Univ. (United States); P. M. Fochuk, Chernivtsi National Univ. (Ukraine); M. Hirt, Univ. of Michigan (United States); A. Hossain, K. Kim, Brookhaven National Lab. (United States); O. V. Kopach, Chernivtsi National Univ. (Ukraine); N. D. Sferrazza, Brookhaven National Lab. (United States); J. Sturgess, Vanderbilt Univ. (United States); K. Polack, Univ. of Michigan (United States); B. Raghothamachar, Stony Brook Univ. (United States); G. Yang, R. B. James, Brookhaven National Lab. (United States) 
7449 OA Simulation of electric field profile in semi insulating Au/CdZnTe/Au detector under flux (Invited Paper) [7449-09]

J. Franc, R. Grill, Charles Univ. in Prague (Czech Republic); R. James, Brookhaven National Lab. (United States); J. Kubat, E. Belas, P. Hoschl, P. Moravec, P. Praus, Charles Univ. in Prague (Czech Republic)

7449 OC Electric field distribution of cadmium zinc telluride (CZT) detectors [7449-11]

G. Yang, A. E. Bolotnikov, G. S. Camarda, Y. Cui, A. Hossain, K. Kim, R. B. James, Brookhaven National Lab. (United States)

\section{SESSION 4 SCINTILLATORS I}

7449 OE Dual gamma neutron detection with $\mathrm{Cs}_{2} \mathrm{LiLaCl}_{6}$ [7449-13]

J. Glodo, R. Hawrami, E. van Loef, W. Higgins, U. Shirwadkar, K. S. Shah, Radiation Monitoring Devices, Inc. (United States)

$7449 \mathrm{OF} \quad \mathrm{Srl}_{2}$ scintillator for gamma ray spectroscopy [7449-14] N. J. Cherepy, B. W. Sturm, O. B. Drury, T. A. Hurst, S. A. Sheets, L. E. Ahle, C. K. Saw, M. A. Pearson, S. A. Payne, Lawrence Livermore National Lab. (United States); A. Burger, Fisk Univ. (United States); L. A. Boatner, J. O. Ramey, Oak Ridge National Lab. (United States); E. V. van Loef, J. Glodo, R. Hawrami, W. M. Higgins, K. S. Shah, Radiation Monitoring Devices, Inc. (United States); W. W. Moses, Lawrence Berkeley National Lab. (United States)

7449 OG Angular resolution obtained with a $\mathrm{LaBr}_{3}$-based rotational modulator [7449-15] B. S. Budden, G. L. Case, M. L. Cherry, Louisiana State Univ. (United States)

\section{SESSION 5 CDTE}

7449 ol Development of a novel energy-resolved photon-counting detector for gamma ray imaging applications [7449-17]

L.-J. Meng, J. W. Tan, Univ. of Illinois at Urbana-Champaign (United States); K. Spartiotis, T. Schulman, Oy AJAT Ltd. (Finland)

7449 0J High-speed photon counting processing for CdTe detector [7449-18] B. Shinomiya, A. Koike, H. Morii, T. Okunoyama, Y. Neo, H. Mimura, T. Aoki, Shizuoka Univ. (Japan)

$7449 \mathrm{OL} \quad$ Far-IR reflectance spectra analysis of CdZnTe and related materials [7449-20] T.-R. Yang, S.-H. Jhang, Y.-H. Shih, National Taiwan Normal Univ. (Taiwan); F.-C. Hou, Y.-C. Yang, National Taiwan Univ. (Taiwan); P. Becla, Massachusetts Institute of Technology (United Kingdom); D.-C. Tien, National Taipei Univ. of Technology (Taiwan); Z. C. Feng, National Taiwan Univ. (Taiwan) 
7449 ON Characterization of secondary phases in modified vertical Bridgman growth CZT (Invited Paper) [7449-22]

M. C. Duff, Savannah River National Lab. (United States); K. G. Lynn, K. Jones, Washington State Univ. (United States); Z. R. Dai, J. P. Bradley, N. Teslich, Lawrence Livermore National Lab. (United States)

$7449 \mathrm{OQ}$ Synchrotron radiation x-ray absorption fine-structure and Raman studies on CdZnTe ternary alloys [7449-25]

Y. L. Wu, Y.-T. Chen, Z. C. Feng, National Taiwan Univ. (Taiwan); J.-F. Lee, National

Synchrotron Radiation Research Ctr. (Taiwan); P. Becla, Francis Bitter National Magnet Lab., MIT (United States); W. Lu, Fisk Univ. (United States)

\section{SESSION 7 CRYSTAL GROWTH}

7449 OU Unseeded growth of CdZnTe:In by THM technique [7449-29]

U. N. Roy, S. Weiller, J. Stein, A. Gueorguiev, ICx Radiation (United States)

\section{SESSION 8 IMAGING APPLICATIONS}

7449 OX The ECLAIRs telescope onboard the SVOM mission for gamma-ray burst studies [7449-32] H.-E. Triou, B. Cordier, D. Gotz, S. Schanne, T. Tourrette, CEA, Saclay (France); P. Mandrou, R. Pons, O. Godet, N. Remové, D. Barret, Ctr. d'Etude Spatiale des Rayonnements, CNRS, UPS (France); J. Atteia, LATT (France); M. Jouret, Ctr. National d'Études Spatiales, CST (France)

7449 OY A quantum-limited CMOS-sensor-based high-speed imaging system for time-resolved x-ray scattering [7449-33]

B. Rodricks, B. Fowler, C. Liu, J. Lowes, Fairchild Imaging (United States); L. J. Koerner, M. W. Tate, Cornell Univ. (United States); S. M. Gruner, Cornell Univ. (United States) and Cornell High Energy Synchrotron Source (United States)

7449 OZ Characterisation of an asymmetric AGATA detector [7449-34]

C. Unsworth, A. J. Boston, H. C. Boston, S. Colosimo, J. Cresswell, M. R. Dimmock, F. Filmer, D. Judson, S. Moon, P. J. Nolan, M. J. Norman, M. Slee, Univ. of Liverpool (United Kingdom)

\section{SESSION $9 \quad$ NEUTRON DETECTORS}

744910 Neutron detector based on TimePix pixel device with micrometer spatial resolution (Invited Paper) [7449-35]

J. Jakubek, S. Pospisil, Czech Technical Univ. in Prague (Czech Republic); J. Uher, Czech Technical Univ. in Prague (Czech Republic) and CSIRO Minerals (Australia)

$744911 \quad$ Neutron detection with single crystal organic scintillators (Invited Paper) [7449-36]

N. P. Zaitseva, J. Newby, S. Hamel, L. Carman, M. Faust, V. Lordi, N. J. Cherepy, W. Stoeffl, S. A. Payne, Lawrence Livermore National Lab. (United States) 
744912 Praseodymium activation detector for measuring bursts of 14MeV neutrons [7449-37]

B. T. Meehan, E. C. Hagen, National Security Technologies, LLC (United States); C. L. Ruiz, G. W. Cooper, Sandia National Labs. (United States)

744913 Neutron energy measurements in emergency response applications [7449-38] S. Mukhopadhyay, P. Guss, M. Hornish, S. Wilde, T. Stampahar, M. Reed, Remote Sensing Lab. (United States)

744914 Multi-element neutron energy spectrometer [7449-39]

S. Mukhopadhyay, R. Maurer, R. Wolff, S. Mitchell, A. Reed, Remote Sensing Lab., National Security Technologies, LLC (United States)

\section{SESSION 10 CHALCOGENIDE DETECTORS}

744918 Properties of layered crystals for radiation detectors: TIGaSe 2 system [7449-43]

D. J. Knuteson, N. B. Singh, D. Kahler, B. Wagner, A. Berghmans, S. McLaughlin, K. Schwartz, Northrop Grumman Corp. (United States)

\section{SESSION 11 CMT AND TIBR}

7449 1A Effect of Te inclusions on internal electric field of CdMnTe gamma-ray detector [7449-45] O. S. Babalola, Vanderbilt Univ. (United States), Fisk Univ. (United States), and Brookhaven National Lab. (United States); A. E. Bolotnikov, S. U. Egarievwe, A. M. Hossain, Brookhaven National Lab. (United States); A. Burger, Fisk Univ. (United States); R. B. James, Brookhaven National Lab. (United States)

7449 1D Fabrication of TIBr strip detectors [7449-48]

K. Hitomi, Y. Kikuchi, M. Nakhostin, Tohoku Univ. (Japan); T. Shoji, Tohoku Institute of Technology (Japan); K. Ishii, Tohoku Univ. (Japan)

\section{SESSION 12 SCINTILLATORS II}

7449 1E Rare-earth tri-halides methanol-adduct single-crystal scintillators for gamma ray and neutron detection (Invited Paper) [7449-49]

L. A. Boatner, D. J. Wisniewski, J. S. Neal, Z. W. Bell, J. O. Ramey, J. A. Kolopus,

B. C. Chakoumakos, R. Custelcean, M. Wisniewska, K. E. Pena, Oak Ridge National Lab. (United States)

7449 1G High-resolution $x$-ray and $y$-ray imaging using a scintillator-coupled electron-multiplying CCD [7449-52]

D. Hall, A. Holland, The Open Univ. (United Kingdom)

\section{SESSION 13 OTHER NOVEL DETECTOR MATERIALS}

$7449 \mathrm{1H}$ Semiconducting material property relationships: trends and their impact on design of radiation detection materials [7449-53]

K. F. Ferris, S. K. Lockersbie, B.-J. M. Webb-Robertson, Pacific Northwest National Lab. (United States); D. M. Jones, Proximate Technologies, LLC (United States) 
$744911 \quad$ Flexible radiation dosimeters incorporating semiconducting polymer thick films [7449-54]

C. A. Mills, A. Intaniwet, M. Shkunov, J. L. Keddie, P. J. Sellin, Univ. of Surrey (United Kingdom)

\section{POSTER SESSION}

7449 1M Bismuth tri-iodide radiation detector development [7449-58]

A. T. Lintereur, W. Qiu, J. C. Nino, J. E. Baciak, Univ. of Florida (United States)

7449 IP Comparison of neutron sensitive scintillators for use with a solid-state optical detector [7449-61]

S. Mukhopadhyay, C. Stapels, E. B. Johnson, E. C. Chapman, P. S. Linsay, Radiation Monitoring Devices, Inc. (United States); T. H. Prettyman, Planetary Science Institute (United States); M. R. Squillante, J. F. Christian, Radiation Monitoring Devices, Inc. (United States)

7449 IR Generic materials property data storage and retrieval for the semiconducting materials knowledge base [7449-63]

D. M. Jones, Proximate Technologies, LLC (United States); K. F. Ferris,

B.-J. M. Webb-Robertson, Pacific Northwest National Lab. (United States); J. T. Muellerleile, Proximate Technologies, LLC (United States); R. W. Hyatt, Battelle Memorial Institute (United States)

7449 IU HgS: a rugged, stable semiconductor radiation detector material [7449-66] M. R. Squillante, W. M. Higgins, H. Kim, L. Cirignano, G. Ciampi, A. Churilov, K. Shah, Radiation Monitoring Devices, Inc. (United States)

7449 IW Design and modeling of a lateral a-Se MSM photoconductor as indirect conversion x-ray imager [7449-68]

K. Wang, Univ. of Waterloo (Canada) and Thunder Bay Regional Research Institute (Canada); F. Chen, Univ. of Waterloo (Canada); G. Belev, S. O. Kasap, Univ. of Saskatchewan (Canada); K. S. Karim, Univ. of Waterloo (Canada)

Author Index 
Downloaded From: https://www.spiedigitallibrary.org/conference-proceedings-of-spie on 25 Apr 2023

Terms of Use: https://www.spiedigitallibrary.org/terms-of-use 


\title{
Conference Committee
}

\author{
Program Track Chair
}

Sandra G. Biedron, Argonne National Laboratory (United States)

Massimo Altarelli, Deutsches Elektronen-Synchrotron (Germany)

Allen H.-L. Huang, University of Wisconsin, Madison (United States)

Conference Chairs

Ralph B. James, Brookhaven National Laboratory (United States)

Larry A. Franks, U.S. Department of Energy (United States)

Arnold Burger, Fisk University (United States)

Program Committee

Toru Aoki, Shizuoka University (Japan)

H. Bradford Barber, The University of Arizona (United States)

Zane W. Bell, Oak Ridge National Laboratory (United States)

Lynn A. Boatner, Oak Ridge National Laboratory (United States)

Aleksey E. Bolotnikov, Brookhaven National Laboratory (United States)

Henry Chen, Redlen Technologies (Canada)

Nerine J. Cherepy, Lawrence Livermore National Laboratory (United States)

Jeffrey J. Derby, University of Minnesota (United States)

F. Patrick Doty, Sandia National Laboratories (United States)

Martine C. Duff, Savannah River National Laboratory (United States)

Michael Fiederle, Albert-Ludwigs-Universität Freiburg (Germany)

Jonathan E. Grindlay, Harvard-Smithsonian Center for Astrophysics (United States)

Yoshinori Hatanaka, Aichi University of Technology (Japan)

Zhong He, University of Michigan (United States)

Keitaro Hitomi, Tohoku Institute of Technology (Japan)

Alan Janos, U. S. Department of Homeland Security (United States)

Warnick J. Kernan, Pacific Northwest National Laboratory (United States)

Glenn F. Knoll, University of Michigan (United States)

Henric S. Krawczynski, Washington University in St. Louis (United States)

Patty Lee, Brookhaven National Laboratory (United States)

Longxia Li, Yinnel Tech, Inc. (United States)

Kelvin G. Lynn, Washington State University (United States)

Manoj Mahajan, Brookhaven National Laboratory (United States)

Krishna C. Mandal, EIC Laboratories, Inc. (United States) 
Jim L. Matteson, University of California, San Diego (United States)

Douglas S. McGregor, Kansas State University (United States)

Ann M. Parsons, NASA Goddard Space Flight Center (United States)

Raulf M. Polichar, Science Applications International Corporation (United States)

Michael M. Schieber, The Hebrew University of Jerusalem (Israel)

Carolyn E. Seifert, Pacific Northwest National Laboratory (United States)

Paul J. Sellin, University of Surrey (United Kingdom)

Michael R. Squillante, Radiation Monitoring Devices, Inc. (United States)

Csaba Szeles, eV Products (United States)

Tumay O. Tumer, Nova R\&D, Inc. (United States)

Sergey E. Ulin, Moscow Engineering Physics Institute (Russian Federation)

Lodewijk van den Berg, Constellation Technology Corporation (United States)

Peter E. Vanier, Brookhaven National Laboratory (United States)

Nikolay B. Zaletaev, Orion Research and Production Association (Russian Federation)

Session Chairs

1 CZT Detectors I

Michael R. Squillante, Radiation Monitoring Devices, Inc.

(United States)

2 CZT Characterization I

Robert D. McLaren, Consultant (United States)

3 CZT Detectors II

Kevin Gutierrez, U.S. Department of Homeland Security (United States)

4 Scintillators I

Henry Chen, Redlen Technologies (Canada)

5 ColTe

Michael Fiederle, Albert-Ludwigs-Universität Freiburg (Germany)

6 CZT Characterization II

Kelvin G. Lynn, Washington State University (United States)

7 Crystal Growth

Robert D. McLaren, Consultant (United States)

$8 \quad$ Imaging Applications

Henry Chen, Redlen Technologies (Canada) 
$9 \quad$ Neutron Detectors

Zane W. Bell, Oak Ridge National Laboratory (United States)

10 Chalcogenide Detectors

Paul J. Sellin, University of Surrey (United Kingdom)

11 CMT and $\mathrm{TIBr}$

Keitaro Hitomi, Tohoku Institute of Technology (Japan)

12 Scintillators II

Larry A. Franks, U. S. Department of Energy (United States)

13 Other Novel Detector Materials

Giuseppe S. Camarda, Brookhaven National Laboratory (United States) 
Downloaded From: https://www.spiedigitallibrary.org/conference-proceedings-of-spie on 25 Apr 2023

Terms of Use: https://www.spiedigitallibrary.org/terms-of-use 


\section{Introduction}

This book contains the proceedings of the SPIE Conference on Hard X-Ray, Gamma-Ray, and Neutron Detector Physics XI. The conference was held on August 3-6, 2009 in San Diego, California. The conference was organized into technical sessions on cadmium zinc telluride (CZT), cadmium telluride, scintillators, crystal growth, neutron detectors, chalcogenide materials, CMT and $\mathrm{TIBr}$, imaging, and novel semiconductor detector materials. A plenary presentation and a poster session were also provided.

The purpose of the conference was to provide a forum for scientists and engineers from the detector development and user communities to present and evaluate the most recent results on X-ray, gamma-ray, and neutron detectors and to discuss the requirements for a variety of radiation-sensing and imaging applications. The primary theme of the conference was on development of improved semiconductor and scintillator radiation detectors and imaging arrays, which combine the advantages of room-temperature operation with the ability to spectrally resolve the energies of emitted X-and gamma-rays. By eliminating the cryogen, new radiation-sensing instruments, such as spectrometers, gamma cameras, and radiographic systems, can be manufactured that are portable, lightweight, easy to operate, and relatively maintenance-free. Recent research and development on detectors have resulted in measurable progress in the availability of single detectors and imaging arrays. In addition, recent reports of the material properties limiting the performance of semiconductor and scintillator detectors have provided new insights and directions to address deficiencies in the crystals and devices.

Despite the limitations on efficiency and relatively high cost of current roomtemperature semiconductor detectors, they have been increasingly deployed in systems useful for medical diagnostics, space applications, safeguarding of nuclear materials, material identification, baggage scanning, position sensing, and gamma-ray spectroscopy. Although significant progress has occurred over recent years, there is still a pressing need to lower the cost of the detectors and to increase the efficiency of room-temperature semiconductor detectors without degrading their spectral performance.

A total of 61 presentations, oral and poster, were given at the conference. Although the number of attendees varied with the session and day of week, the attendance averaged approximately 70 people with a substantial fraction of those in attendance representing organizations outside of the United States. The plenary session drew over 200 attendees.

This book provides detailed documentation describing a portion of the presentations. The editors hope that it will serve as an important record of the 
meeting, provide an update on the status of X-ray, gamma-ray, and neutron detector technology, and serve as a useful source of information for those working in the field.

The conference chairs would like to thank the session chairs and members of the conference program committees, who offered their time to enlist the involvement of many researchers working in the field.

Ralph B. James

Larry A. Franks

Arnold Burger 